\title{
How environmental stewardship is viewed and evidenced in the Uniting Reformed Church of Southern Africa: An appraisal of students', lecturers' and ministers' perceptions
}

\author{
Le Roux, Cheryl S \\ University of South Africa \\ lroux@unisa.ac.za
}

\begin{abstract}
To care for the environment as part of a Christian believer's Christian stewardship duty is biblically founded. The Church is consequently well-positioned to make a significant contribution in addressing the environmental crisis by developing, preaching and practising a holistic spirituality that promotes a custodial ethic towards the natural world. The research report discusses how seminary students, lecturers and practicing ministers in the Uniting Reformed Church of Southern Africa perceive and practise this custodial ethic as environmental stewardship. There is consensus amongst respondents that Christian stewardship and environmental stewardship are biblically mandated and should be addressed and practised in the Church. However, the findings provided evidence that the realisation of environmental stewardship is tentative, both within the ministry and within seminary programmes. It is concluded that the teaching and practice of environmental stewardship is generally neglected in the Church. Areas for improvement in the ministry and seminary training curricula to support environmental stewardship are suggested.
\end{abstract}

Key words

Christian stewardship; environmental stewardship; Uniting Reformed Church of Southern Africa; environmental literacy

\section{Introduction}

Despite the fact that the Bible, as the inspired Word of God, deals primarily with the relationship between God and humankind and the way to salvation and eternal life through Jesus Christ, the Bible also outlines the splendour and importance of creation and presents principles which indicate how the 
natural environment should be used and preserved (Bauckman 2002:141; Esler 1998:223-224; Horrell, Hunt \& Southgate 2008:223-224; Ps 8:3-8; I Ch 16:7, 30-34; Job 9:5-10; Rom 1:20; 3:23; 5:8; 6:23; 10: 9 \& 13. Part of God's provision for the welfare of humankind is that He created and mandated the use of plants, animals and resources (the biophysical world) to meet humankind's physical and material needs (Bergstrom 2003; Gen 2:9, 12). According to Bergstrom (2003) one of the reasons God created and continues to sustain nature - apart from the enjoyment He himself derives from His creation - is to help meet people's needs such as food and shelter and to support this view Bergstrom cites Genesis 2:15 and Genesis 9:3. This biophysical world created to sustain humankind was also created for humankind's pleasure and admiration (Job 37:14-18; Ps 104:24). These precepts - although written centuries ago - remain relevant.

However, environmental conditions have been seriously compromised in the current age through human greed, materialism, self-indulgence, competitiveness and short-sightedness (Page, in Esler 1998:223-224; Cafaro 2005; Taliaferro 2005:162). These specific human traits that have led to the degradation of the environment are ardently opposed by Christianity (2 Cor 8:9; Heb 13:5; Lk 12:15; Matt 6:19; Phil 2:3), yet as Apple (2009:98) suggests, the Christian Church, as one of the dominant global religions, is not blameless. It should accept responsibility for perhaps not sufficiently taking in hand humankind's action that has led to the current exploited state of the natural world. It is hereby inferred that the Church has a role to play in safeguarding the environment and it is this sentiment which led to the research being undertaken.

\section{Research methods and context}

A mixed method approach was used in this study which followed a case study design. A case study is an empirical inquiry that focuses on a contemporary phenomenon within its real-life context (Yin 1994: 23). As a mixed methods study, the research thus followed both quantitative and qualitative approaches and incorporated their associated data collection methods and instruments. The rationale for using mixed methods according to Chow, Quine and $\mathrm{Li}$ (2010:491) is that it offers the researcher the opportunity to collect rich data which produces robust research 
results. A mixed methods paradigm adds complexity to the research design, increases the comprehensiveness of overall findings and increases the methodological rigour as findings in both phases can be checked for consistency.

The study was conducted amongst a cohort of ministers of the Uniting Reformed Church in Southern Africa (URCSA), lecturers and students at various URCSA training institutions and seminaries and a group of church elders. In total, three hundred and sixty ministers, twenty lecturers, twentythree final year B.Th. students and fifteen church elders participated in the study. All participants were black males between the ages of 20 and 65 . The data for the study was collected through a questionnaire which was quantitatively analysed. Individual and focus group interviews were also conducted of which the data was analysed qualitatively.

The research reported on in this article arises from the findings of the individual and focus group interviews. A total of fifty-eight ministers and seven lecturers who are also ministers of the URCSA were individually interviewed - either in person or telephonically - using a semistructured interview schedule. Nine final-year seminary students from two different institutions were interviewed individually and two focus group interviews with seven final-year students each were conducted. The study was conducted over three years, and the interviews were conducted in the final year of data collection. The interviews were recorded and transcribed and the ensuing data was analysed according to Tesche's model of qualitative data analysis. Respondents were from Gauteng, Limpopo, North West and the Western Cape and were selected through convenience sampling.

This article focuses on the findings that emanated from the individual and focus group interviews conducted with ministers, lecturers and students. The themes that emerged from the interviews related to Christian stewardship as a dimension of the Christian ethic; environmental stewardship as a dimension of Christian stewardship; Christian stewardship and environmental stewardship within the ministry, seminaries and training institutions; and the perceived significance of, need for and level of environmental literacy amongst respondents as a means of establishing and practicing environmental stewardship. 
To contextualise the findings of the research, it is necessary to first outline the theoretical framework of the study, the key concepts and underlying assumptions.

\section{Theoretical framework, key concepts and underlying assumptions}

The function of the Christian Church is primarily to proclaim the Gospel and to lead sinners to Christ (Acts 1:8; Matt 28:18-20; 1 Pet 3:15). However, given that "man is created in the image of God" (Gen 1:27), humankind is directed to care for the natural environment as part of responsible Christian living through which we honour God and witness to the world (Matt. 5:16). Conradie and Field (2000: 1), Clarke (2007) and James (2009) point out that the Church has an important role to play in raising environmental awareness and promoting environmentally responsible actions among its followers. Such actions should be seen as part of the Christian's Christian stewardship duty as biblically mandated (Js 1:21; Jn 14:15-17; 1 Jn 4:20; Mk 12:29-31). Furthermore, these actions are also duties of environmental stewardship and are not distinct from the duty of Christian stewardship since environmental stewardship and Christian stewardship are mutually inclusive as both have as impetus honouring and bringing glory to God (Barkey 2000;1 Cor 10:31). Christians are consequently required to nurture and protect the environment and be knowledgeable about and engage with environmental issues as part of exercising their environmental stewardship duty. To do this, it can be conjectured that ministers within the Church are mandated to include teaching about humankind's responsibility of care, compassion, ownership and accountability towards the natural creation within their sermons and engagement with the broader congregation. Aspiring ministers in the Church will require germane tuition in this field to prepare them for their task once qualified. Within the Church and seminaries, one would expect to find and have available, appropriate material that relates to the environment in order to meet this duty.

Key concepts integral to the study are the notions of stewardship, Christian stewardship, environmental stewardship, and environmental literacy. To contextualise the study, these concepts require clarification and are subsequently discussed below. 


\section{Stewardship}

Within a secular context, according to Travis, Egger, Davies and Mechbal (2002), stewardship is defined as the careful and responsible management of the wellbeing of that of which one is a steward. Stewards are caretakers and their stewardship duties involve deciding what should be done, and how it should be done. In other words, stewards need to collect and use information; provide vision and direction; plan and implement strategies; put structures in place to implement the directives and exert influence to ensure that the goals are reached. Stewards are accountable for the degree of success of their stewardship and this success or lack thereof is assessed by determining the wellbeing of the entity of which stewardship is provided. Stewardship can be summarised as an ethic that embodies the responsible organisation, development and management of resources.

\section{Christian stewardship}

The primary objective of the Church is to bring people into a closer relationship with God so that through the Holy Spirit they might be led to repentance and brought to salvation (cf Acts 2:42). A key strategy to accomplish this within the Church is to encourage individuals to recognise the gifts God has given them - physical, material and spiritual - and to inspire them to attend to what God is calling them to do (2 Cor 9:6; Lk 6: 30, 38; Matt 6:1-4; Matt 28:18-20; Prov 3:9) so that they use their gifts to bring themselves and others to become more like Christ. Christian stewards, empowered by the Holy Spirit, thus commit themselves to conscious, purposeful decisions regarding how to use the gifts God has given them to achieve this objective.

In the biblical context, a steward holds a position of trust, although in some instance this position is abused (Gehman 1970:906; see the parable of the unjust steward in Lk 16:1-13). Paul (1 Cor 4:2; Titus 1:7-9) and Peter (1 Pet 4:10) outline the characteristics and requirements of stewards as individuals who should be trustworthy, blameless, respectful, charitable, self-controlled, upright and disciplined. Stewards are mandated to encourage compliance and oppose wrongdoing. Christian stewardship is consequently displayed in seeking justice, peace and the integrity of creation in an interdependent universe, wisely employing God-given human resources and abilities; sharing the material resources by holding 
and giving them in service, justice and compassion and providing for others, sharing in the life, worship and responsible stewardship of the Church and of its mission both for the individual and for the community (Episcopal Church Centre 2002a).

Stewardship is thus the regular practice of returning to God a portion of all that God has given us. It involves teaching ourselves how to create a life built upon the notion that all that we have is a gift from God (Episcopal Church Centre 2002b). Like the servants in the Parable of the Talents, we will be called to give an account of how we have administered everything we have been given, including our time, money, abilities, information, wisdom, relationships, and authority (Matt 25:14-25,30).

\section{Environmental stewardship}

Environmental stewardship in the secular context refers to responsible use and protection of the natural environment and its resources through conservation and sustainable practices to ensure a sustainable future (EPA 2016; EPA 2005: 2, 12). This use and protection of the environment is carried out in a way that takes full and balanced account of the interests of society, future generations and species apart from humans (Worrell \& Appleby 2000:263). Aldo Leopold (1887-1949) championed environmental stewardship based on a land ethic which was conceived of as dealing with humankind's relation to land, animals and the plants which grow upon it (Leopold 1949). Current analysis of the global state of the environment clearly indicates that humankind overall has not exercised responsible environmental stewardship, but has carelessly disregarded conservation and environmental equilibrium and consequently faces a critical global socio-environmental crisis (Temocin 2016).

\section{Environmental stewardship from a biblical perspective}

The words "steward" and "stewardship" are used throughout the Bible (Gen 15:2; 44:1; 1 Chr 28:1; Matt 20:8; 1 Cor 4:2; Lk 12:42; 16:1-2). The word used for steward can be interpreted as manager or servant and refers to a person who is put in charge of taking care of something that does not belong to him or her. In Genesis 1 (26-31) and 2 (16-17) believers are acquainted with the fact that they are the appointed stewards of God's created physical world. God gave His people authority over nature not 
as owner or exploiter, but as steward who shares the creative care of the Creator (Northcott 1996:180). Reumann (1992:5) claims that Christian stewardship and environmental stewardship is a person's grateful and obedient response to God's redeeming love, expressed by the judicious use and care of His creation.

As Esler (1998:219-221) points out, an environmental steward is responsible for the conservation of the land, so that it will not go to waste; responsible for its improvement, so that it becomes more productive; and responsible for the care of fellow creatures, the non-human inhabitants. Christians are thus required to tread judiciously on the earth, to use its resources wisely and to nurture and protect it (Birch, in Habel \& Wurst 2000:11).

In Exodus, we find a number of unambiguous principles describing God's instructions for how His creation should be treated. For example, there was the introduction of the Sabbath principle. According to the Sabbath principle, people are required to set aside the seventh day as a day of rest for people and animals (Ex 20 \& Deut 5) and in Exodus 23:10-12 and Leviticus 25:2-4 God instructs that all cultivated lands are to be let rest and lie fallow in the seventh year (2 Chr 36:21). These Sabbath principle commandments protect man, beasts and the natural environment from relentless exploitation, ensure their sustainable use and allow for rejuvenation and restoration (DeWitt 1994). Principles regarding sanitation and waste disposal are outlined in Leviticus $17: 1-27 ; 34$. These principles point to conditions that outline how creation is to be used, but also cared for and protected.

God warns through Isaiah (5:8) that wretchedness will befall those who use His creation in an exploitive manner and reproaches those who abuse the physical environment (Ezek 34:2-4, 18; Jer 2:7). He warns against those who destroy the earth (Lev 25:23-24; Rev 11:18). God speaks to humankind through the Scriptures, but also through His creation (Ps 19:1-4; Matt 6:28-29; Rom 1:20) and we cannot claim ignorance regarding how creation should be used and cared for.

God gave people dominion over nature (Gen 1:26, 28; 2:15), but since people are created in the image of God (Gen 1:28) as His representatives on earth, it follows that we need to attach similar values to nature and its use. The instruction to have dominion over the earth is predicated upon the fact 
that God is the ultimate owner of all things and that human subjugation and use of the earth must be in accordance with God's will and bidding. Humans have dominion over the earth, but are not sovereign over it (Job $38: 1-39: 40)$. Taking custody of the earth implies an understanding of the elements of nature or natural systems and learning about God's created order and purpose of nature (Bergstrom 2003). Christianity undisputedly recognises human stewardship of the created world.

\section{Environmental literacy}

An environmentally literate person is one who has a broad understanding of how people and societies relate to each other and to natural resources, and how they might do so sustainably (Elder 2003:15). Environmental literacy presupposes awareness and knowledge of the environment and its interrelatedness, a pro-environmental attitude and the intellectual and pragmatic skills needed to incorporate appropriate environmental considerations into daily decisions about consumption, lifestyle, career and civics, and to engage in individual and collective pro-environmental activities (Elder 2003:16-17). Environmental literacy is thus activated by individual commitment.

Environmentally literate citizens are motivated and empowered to act on their own informed conclusions to ensure environmental quality and sustainability. This latter disposition translates to later working in groups and communities and cultivating an understanding of ways of benefiting the environment. The deduction is that educators and individuals, whether they serve and function in the secular or religious context, need to facilitate and encourage these proenvironmental dispositions and skills in broader community contexts.

The underlying assumptions regarding the relationship between environmental literacy and environmental stewardship through training are outlined below.

\section{Training in environmental literacy and environmental stewardship}

Gambrill (2011:12) mentions that Christian communities are excellently positioned to teach about the environment since Christianity has within it both implicit and explicit environmentally related teaching opportunities. Christianity's central theme is about the condition of man, his relationship 
with God and his salvation and consequently the Church is often accused that teaching about the environment is seen to be of minor importance. However, the explicit teaching about the environment is most significantly supported in the narrative of the creation of Adam. He is created separately to the rest of creation, and his authority and dominion over it is made apparent (Gen 1:26-28). Creation is there for his use - but not exploitation. When God placed Adam in the Garden of Eden he was instructed to tend and keep it (Gen 2:15) and the Garden of Eden was thus assigned to his care and protection.

In our everyday existence, we are increasingly confronted with the need for frugality, social eco-justice, and fair access to the use and distribution of natural resources (UN Millennium Declaration 2000). People need to show responsibility towards the natural world and be accountable to the common good of the current and future generations. This notion is intrinsic to the concept of sustainable development (SD) articulated at the UN World Commission on Environment and Development (WCED 1987). Although the term SD has been in circulation since 1987, it was only in 2002 that it was acknowledged that "education" was an indispensable means to achieve SD (Centre for Environmental Education 2008; UNESCO 2010).

The issue of responsibility and accountability mentioned above can be nurtured through appropriate educational interventions as envisaged through the Decade for Education for Sustainable Development (DESD) instituted in 2005. Owing to the substantial following the Christian Church has, it is fair to assume that the Church has the ability to reach out to and educate vast numbers of individuals, and in the context of this study, educate them in relation to the concept of ES. Simultaneously, the Church is scripturally duty bound to fulfil its mandate to value and treat creation with respect (Col 1:17; Heb 1:3, 10-12; Ps 19:1-6; Ps 102:25-27; Ps 103:19-22; Ps 104) and to exercise stewardship over the earth (Gen. 1:26-28; Ps 8:5) and hence to ensure that believers are educated about their environmental stewardship mandate.

If this assumption is valid, in the context of this study, it is necessary to establish how ministers of URCSA view Christian stewardship and environmental stewardship as being dimensions which should feature in their edification of their congregations. Related to this is to establish their level of environmental literacy since it could be conjectured, this could 
affect their ability to practise and teach about environmental stewardship. Furthermore, students' and lecturers in theological seminaries' views and depth of understanding of the same concepts need to be established.

\section{Research questions and aims}

To build a premise that in the URCSA context there is a distinct need to teach about the significance of and care for the biophysical and environmental components of God's creation as part of a Christian stewardship ethic, the following research questions were posed:

- What are URCSA ministers', lecturers' and students' views on Christian stewardship as a dimension of the Christian ethic in their ministry or training?

- What are URCSA ministers', lecturers' and students' views on environmental stewardship being a dimension of Christian stewardship in their ministry or training?

- To what extent do URCSA ministers, lecturers and students experience that Christian stewardship and environmental stewardship are manifest, taught and practised in the Church, seminaries and communities?

- What is the level of, perceived need for and significance of environmental literacy among URCSA ministers, lecturers and students as a means of establishing environmental stewardship?

The research consequently aimed to establish how environmental stewardship is perceived and evidenced in URCSA through examining interviewees' views on Christian stewardship being Biblically founded; the link between environmental stewardship and Christian stewardship; the extent to which Christian stewardship and environmental stewardship are manifest in the Church, training institutions and community, and how environmental literacy is perceived to be related to their ability to teach and practise environmental stewardship.

\section{Presentation and discussion of the research findings}

The research findings are presented according to the themes that were evidenced during the data analysis phase. 


\section{Christian stewardship as a dimension of the Christian ethic}

Ministers were unanimous that Christian stewardship is a core feature of the Christian ethic and that it is an important Christian responsibility. Stewardship is a part of how Christians respond to the salvation they received by faith and grace. One respondent explained that it is one's faith and gratitude for salvation that drives one to become answerable to God. Christians accept Christian stewardship as being fundamental to human existence and their life in general since one's religion or beliefs and how one lives one's everyday life cannot be separated. Christian stewardship is ultimately a way of Christian living.

URCSA ministers are all familiar with the concept Christian stewardship and readily accept that the demonstration of and teaching on the topic are imperative to their task in the Church. Ministers are furthermore expected to lead by example and exhibit Christian stewardship in their daily lives. One interviewee responded as follows:

Christian stewardship forms an integral part of one's ministry in the sense that God has called and placed ministers in a position of leadership in this ministry; to lead and guide the congregation towards values of the kingdom of God. Ministers are called upon to teach and to empower other members of the congregation to follow the example set by them and be good stewards in building the Church as the body of Christ.

Most of the respondents alluded to the fact that the responsibility of being a steward derives from the fact that Christian believers are called to be God's representatives on earth and subsequently have the duty of care. Everything ultimately belongs to God and as stewards Christians are obliged to take good care of the earth and everything therein. These tenets are biblically rooted (cf Matt 25:14-31; Ps 24:1). As such, all Christians are called to demonstrate and actively practise Christian stewardship. Christian stewardship includes duties such as taking care of God's people and His creation, and of helping improve people's spiritual and physical state. Christian stewards are expected to generously give of their time, abilities and resources in God's service. Through practising Christian stewardship one has the opportunity to bring glory to God. 
Students agreed that the curriculum they follow pertinently integrated training that covers Christian stewardship and consequently they considered themselves to be well-versed on the topic. In their training, regular reference to Christian stewardship as an undisputed responsibility of Christians is elucidated, especially as it pertains to ministers in service of the congregations and the broader community.

From several responses - both from ministers, lecturers and students it could be deduced that interviewees believed that Christian stewardship extends beyond the exclusive care for humankind and is applicable to the care and nurture of all of creation - suggesting a link between Christian stewardship and environmental stewardship.

\section{Environmental stewardship as a dimension of Christian stewardship}

Interviewees consistently agreed that environmental stewardship is a dimension of Christian stewardship, but it was also acknowledged that although congregations should be ministered about both Christian stewardship and environmental stewardship, in most cases ministers focus mostly on Christian stewardship and tend to neglect teaching about environmental stewardship. It was suggested that this was because not all ministers perceive environmental stewardship as a critical feature of their ministry. Interviewees stated that the ministry is a "comprehensive service" and should include teaching about Christian stewardship and about environmental stewardship. However, in the Church environmental stewardship is clearly not perceived to be as important as Christian stewardship. It was pointed out that aspects of the importance of environmental stewardship could be found in the Church's own immediate environment. Very few Churches perceived themselves to be "green" or provided congregants with a basic experience of being aware of or having reverence for the beauty of creation. Ministers acknowledged that there is no excuse for not teaching environmental stewardship. Since the beginning of time, Adam and Eve were tasked to look after the Garden of Eden, that is, the fauna and flora - a mandate which undeniably embodies environmental stewardship.

In keeping with the sentiment that not enough has been done with regard to including teachings on environmental stewardship in the ministry, one minister responded as follows: 
The inclusion of preaching about Christian stewardship is very important in the ministry and must be continuous. But more needs to be done with regard to include teaching about the environment and include reference to teaching about aspects like saving electricity, reducing the number of cars on roads due to carbon dioxide emissions, reducing pot holes on the streets, throwing rubbish away in demarcated areas, correct use of water, planting trees that do not use a lot of water, the use of common transport etcetera as we as Christians are responsible for the environment.

One interviewee commented that nowadays it has become "as if people own everything to themselves and don't care about their surroundings". Furthermore, interviewees commented that their training had not (or did not sufficiently) address environmental stewardship issues and consequently, although they were aware of the importance of environmental stewardship, they felt inadequately prepared to teach on the topic. There was consensus that the lack of training and support in relation to incorporating environmental stewardship in the ministry needed to be addressed as a matter of urgency. During the focus group interview with students, one student remarked as follows:

Taking care of the environment and creation is a must to all of us as citizens of our countries and inhabitants of the planet. Protecting the environment is investing in our own survival and the survival of our children and the generations to come.

Another student commented that:

The Church is within this world and it should help in correcting the ills to which the environment is exposed. Holistic preaching should include the environment and its care. The environment is part of God's nature and we need to teach people in Church about the deeds of God and our responsibilities. People need trees and plants and training on environmental stewardship will assist in the process of curbing soil erosion. However, the training in this regard was not primary to the curriculum.

Having established the perceptions of interviewees on Christian stewardship, environmental stewardship and their interrelatedness as well as to what extent the concepts are included in the ministry and in training 
institutions, the questions that followed dealt specifically with the concepts that underpin ES, namely environmental awareness, interviewees' level of environmental literacy and their overall concern for the state of the environment as an integral dimension of God's creation.

\section{The level of environmental awareness and environmental literacy}

Interviewees were asked to elaborate on their levels of environmental awareness and environmental literacy. In general, interviewees considered themselves to be environmentally aware given that many of the environmental issues are global concerns and are foremost in the media. However, they tended to acknowledge that this awareness did not necessarily ensure that they were knowledgeable about the issues and few considered themselves able to discuss any of the environmental issues experienced beyond reiterating what popular opinion says about these issues. A number of ministers admitted that they have recently been making an effort to become more environmentally literate by reading up about global problems. Some indicated that they had made reference to these issues in their sermons. However, practicing ministers admitted that during their training they had not received any formal tuition on environmental issues which would have enhanced their environmental literacy. The matter of learning about the environment and its issues and concerns were left for individual ministers to search for answers on their own.

One lecturer (who is also a minister) indicated that he viewed his own level of environmental awareness and literacy as very good. This was as the result of having attended and facilitated conferences on globalisation and its effects on the economy and environment. He was aware of and very concerned for the pressing need to take care of and protect the environment. He asserted that teaching others about the need to protect the environment was a priority. His worry was that, despite his attempts to include teaching about one's environmental stewardship duty, his congregants and students still seemed to lack environmental awareness and environmental literacy since there was little evidence that they were giving the environment the attention they should. Congregants in general he believed are not sufficiently environmentally literate despite the extensive environmental campaigns that have been launched throughout the country and in his district. Their awareness was limited to mere familiarity with an environmental issue 
without any real understanding of its essence - its causes, consequences or ways of intervening or addressing the issue. Furthermore, he believed that environmental awareness in itself is unable to change and shape attitudes towards environmentally friendlier ones. In his opinion, insufficient emphasis is placed on the love, respect, or admiration for nature in the ministry in general. His concluding comments were: "We do not perceive nature as part of our ministry and tuition. We only concentrate on winning souls and raising funds for the congregations. The environment is left to tend to itself and we neglect to be amazed by the wonder of creation."

Students generally commented that they were environmentally aware, but didn't necessarily consider themselves to be environmentally literate. It was impossible not to be aware of the global environmental crisis as one is confronted with information about the environmental crisis daily. However, despite being enveloped by the crisis, students commented that learning about the environment and its issues was not included in their formal training programme, apart from a minor section in the Ethics module which is compulsory for all students. There are elective modules in the B.Th. programme which address environmental issues but since they are electives and not compulsory modules, many aspirant ministers could complete their studies without receiving any tuition in relation to the environment. In these modules, study material that enhances awareness and knowledge of the environment is provided, which will therefore promote environmental literacy. Environmental modules provide the framework to better understand the necessity of environmental stewardship. The majority of the students agreed that the inclusion of environmental awareness modules would help them to become aware of and knowledgeable about their environmental stewardship responsibilities and to impart that knowledge in their ministry once qualified. One student remarked that "raising environmental awareness prepares the way for environmental literacy".

Students who had studied one or more of the environmental modules, indicated that it had enabled them to understand the challenge the environmental crisis poses for the Christian faith when one looks at the issues from a biblical point of view. The contents of these modules raised awareness of the environmental crisis and presented arguments relating to the reasons for the crisis and ways of addressing environmental issues. 
However, these modules were presented from a secular point of view and as aspirant ministers they felt that their curriculum should provide more courses devoted to environmental literacy from a biblical perspective to equip them to fulfil their environmental stewardship duty. One student commented as follows: "We are not like spiritual beings, we are part of what happens in the environment where we live and we need to be aware and have knowledge [of the environment]."

\section{The relationship between environmental literacy and environmental stewardship}

Several ministers believed that since they have both a Christian stewardship and environmental stewardship duty, they should seriously engage in training that enhances their environmental literacy and environmental awareness as this would support environmental stewardship. One minister commented that:

Our calling does not end in the pulpit but extends also to love and preserve the natural resources. Ministers need to preach and enlighten people about instances where nature is being destroyed and how it can be preserved thereby demonstrating ES.

The general opinion amongst ministers was that being a Christian is to care about what is currently happening to God's creation. Many interviewees pointed out that Christians cannot ignore the prevailing environmental exploitation, degradation and destruction. Most of the interviewees pointed out that the Bible is very specific about believers' environmental stewardship duty. Christians who are not actively involved in environmental care are not fully living in accordance to one of the most fundamental God-given commands: love for one's neighbour - which extends to the rest of creation and the habitats that sustain them. One minister was particularly adamant about this point and emphasised that:

In Romans 8:18-30 and especially verses twenty-one and twentytwo, it is indicated that creation itself would one day be set free from its slavery to decay and would share the glorious freedom of the children of God and that creation groans with pain, like the pain of childbirth. Galatians 5:22-23 indicate that the spirit produces love, joy, peace, patience, kindness, goodness, faithfulness, humility and 
self-control. In Genesis 9:9-12, God made a covenant with Noah and his descendants and with all living beings - all birds and all animals - everything that came out of the boat with him. God promised that never again will all living beings be destroyed by a flood; never again will a flood destroy the earth.

Students were unanimous that globally the environment is in crisis and that everyone has a moral responsibility to care for the environment and address environmental issues to whatever extent they can. Furthermore, Christians are mandated by God to treat the environment with respect and use it and care for it responsibly. This is an underlying biblical principle. Environmental stewardship is the means through which the Church can contribute to cultivating an ethic of respect for the environment and increase congregants' knowledge of the environment so that they are able to take action to address environmental issues. Ministers should take a lead in this process. Furthermore, students who are aspiring to become ministers need to be adequately prepared for this task.

\section{Conclusions and recommendation}

The study evidenced that practicing ministers, lecturers and students are all in agreement that Christian stewardship and environmental stewardship are biblically rooted and Scripture was liberally quoted to support this view. Furthermore, environmental stewardship is an acknowledged dimension of Christian stewardship and it was a general sentiment that the church has a significant role to play in demonstrating and teaching about Christian stewardship and environmental stewardship - both in the congregation and the broader community. There was consensus that Christian stewardship, environmental stewardship and environmental literacy should be manifest not only by the ministers, lecturers and students, but by all Christians and consequently within the Church. There was some measure of doubt whether the Church was sufficiently sensitive to its environmental stewardship duty and whether the Church in general was sufficiently environmentally literate to practice pro-environmental behaviour and carry out its environmental stewardship responsibility. Ministers did not argue that they had a definite environmental stewardship duty to fulfil, but noted that more could be done to promote environmental stewardship in the Church and the community. There was significant 
room for improvement, but it was proposed that improving environmental literacy would strengthen their ability and resolve to better integrate and practise their environmental stewardship duty.

Currently, tuition that could support environmental literacy in seminary training programmes and thereby environmental stewardship appears to be inconsequential. Knowledge about the environment and a certain level of environmental literacy are precursors for teaching about and demonstrating environmental stewardship and there is indeed a need for greater emphasis on environmental literacy in the B.Th. degree programme. Students revealed their concerns that currently the B.Th. curriculum did not sufficiently include modules which would promote environmental literacy. It is consequently recommended that theological training institutions should critically evaluate the curricula currently presented to determine how environmental literacy which could support students' understanding of the environment and their understanding of their environmental stewardship duty could be enhanced. This recommendation is based on the belief that ministers are biblically mandated to ensure that environmental stewardship is practised. Both Christian stewardship and environmental stewardship need to be adequately addressed in training programmes to ensure that graduates are sufficiently equipped to infuse an environmental ethic that responds to the biblical mandate of environmental stewardship.

Christians should not negate their responsibility towards caring for the environment, but should hold themselves accountable as trusted stewards of God's creation. We know that God created the world, and it belongs to Him, not us. Because of this, we are only stewards or trustees of God's creation, and we aren't to abuse or neglect it. God has clearly placed humans in a position of responsibility over the creation. Christians are accountable to God as stewards of His creation. God has commissioned believers to care for creation in a way that sustains, protects, and enhances His work. Christians are required to manage the environment not simply for their own benefit but for God冈s glory.

\section{Acknowledgement}

The contribution of Rev Dr RD Tshenye (URCSA) to the research of this article is gratefully acknowledged. 


\section{Bibliography}

Apple, MW 2009. Some ideas on interpreting the right: on doing critical educational work in conservative times. Education, citizenship and social justice, 4(2): 87-101.

Barkey, M 2000. Environmental Stewardship in the Judeo-Christian

Tradition: Jewish, Catholic, and Protestant Wisdom on the Environment. [Online]. Available: https://acton.org/public-policy/ environmental-stewardship/theology-e/environmental-stewardship-judeo-christiantraditi [Accessed: 4 July 2017].

Bauckham, RJ 2002. God and the crisis of freedom: Biblical and contemporary perspectives. Louisville: John Knox.

Bergstrom, JC 2003. Principles of a Christian Environmental Ethic: With Applications to Agriculture, Natural Resources, and the Environment. [Online]. Available: http://www.leaderu.com/science/bergstrom-enviroethics.html [Accessed: 11 April 12015].

Bible. 1982. Good News Bible. Today's English Version. The Bible Society of South Africa: Cape Town.

Cafaro, PJ 2005. Gluttony, arrogance, greed and apathy: an exploration of environmental vice. In Environmental virtue ethics, edited by $\mathrm{R}$ Sandler and P Cafaro. Lanham: Rowland \& Littlefield. 135-158.

Centre for Environmental Education. 2008. [Online]. Available: http://www. ceeonline.org/about/about.aspx [Accessed: 15 April 2015].

Chow, MY, Quine S \& Li, M 2010. The benefits of using a mixed methods approach - quantitative with qualitative - to identify client satisfaction and unmet needs in an HIV healthcare centre, AIDS Care, 22(4):491-8.

Conradie, E \& Field, D 2000. A Rainbow over land. Pretoria: Salty Print.

Clarke, G 2007. Agents of transformation? Donors, FBOs and international development. Third World Quarterly, 28(1): 77-96.

Dewitt, CB 1994. Earth-Wise: A biblical response to environmental issues. Grand Rapids, MI: CRC Publications. 
Elder, JL 2003. A field guide to Environmental literacy: Making strategic investments in Environmental Education. Rock Spring: The Environmental Coalition.

EPA. (United States Environmental Protection Agency). 2016. Environmental stewardship. [Online]. Available: https://archive.epa.gov/ stewardship/web/html/ [Accessed: 23 March 2017].

EPA. (United States Environmental Protection Agency). 2005. Every day choices: opportunities for environmental stewardship. [Online]. Available: https://archive.epa.gov/stewardship/web/pdf/rpt2admin.pdf [Accessed: 4 July 2017].

Episcopal Church Centre. 2002a. Office of stewardship. The Allelula Fund: a guide for Dioceses and congregation. [Online]. Available: http://www. eastmich.org/resources/TblSteward.htm [Accessed: 22 July 2013].

Episcopal Church Centre. 2002b. Office of Stewardship. [Online]. Available: www.stewardshippresources.org [Accessed: 22 July 2013].

Esler, PF 1998. Christianity for the twenty-first century. Edinburgh: T\&T Clark Ltd.

Gambrill, A 2011. Practice to policy to practice: connecting faith and conservation in Africa. [Online]. Available: http://www.arcworld.org/ downloads/Practice_to_Policy_to_Practice.pdf [Accessed: 4 April 2013].

Gehman, HS 1970. The New Westminister Dictionary of the Bible. Philadelphia: Westminister.

Habel, NC \& Wurst, S 2000. The earth story in Genesis. England: Sheffield Academic Press.

Horrell, DG, Hunt, C \& Southgate, C 2008. Appeals to the Bible in ecotheology and environmental ethics: a typology of hermeneutical stances. Studies in Christian Ethics, 21:219-238.

James, R 2009. Advantages and challenges for Christian Churches and organizations for doing development work. [Online]. Available: http:// dspace.africaportal.org/jspui/bitstream/123456789/26275/1/Handle\%20with\%20 care\%20-\%20engaging\%20with\%20faith\%20based\%20organisations\%20in\%20 development.pdf?1 [Accessed: 23 March 2017]. 
Leopold, A 1949. A Sand County Almanac. New York: Oxford University Press.

Northcott, MS 1996. The environment and Christian Ethics. New York: Cambridge University Press.

Reumann, JHP 1992. Stewardship and the economy of God. Michigan: William B Eerdmans Publishing Company.

Taliaferro, C 2005. Vices and virtues in religious environmental ethics. In Environmental virtue ethics, edited by R Sandler and P Cafaro. Lanham: Rowman \& Littlefield. 159-172.

Temocin, P 2016. The current environmental crisis. [Online]. Available: http://www.ecosprinter.eu/blog/the-current-environmental-crisis/ [Accessed: 23 March 2017].

Travis P, Egger, D, Davies, P \& Mechbal, A 2002. Towards better stewardship: Concepts and critical issues. [Online]. Available: http:// www.who.int/healthinfo/paper48.pdf [Accessed: 20 March 2017].

UNESCO. 2005. Decade for Education for Sustainable Development. [Online]. Available: http://www.esd-world-conference-2009.org/fileadmin/ download/background/DESD_key_findings_and_way_forward_23March09_4.pdf [Accessed: 4 April 2012].

UNESCO. 2010. Education for all. [Online]. Available: http://www.unescobej. org/education/themes/contributing-to-the-international-agenda/education-for-all/ [Accessed: 4 April 2012].

United Nations Millennium Declaration. 2000. [Online]. Available: http:// www.un.org/millennium/declaration/ares552e.htm [Accessed: 11 April 2012].

WCED. United Nations World Commission on Environment and Development. 1987. [Online]. Available: http://www.un-documents.net/ wced-ocf.htm [Accessed: 11 April 2012].

Worrell, R \& Appleby, MC 2000. Stewardship of natural resources: definition, ethical and practical aspects. Journal of Agricultural and Environmental Ethics, 12(3): 263-277.

Yin, RK 1994. Case Study Research. Design and Methods. $2^{\text {nd }}$ edition. Thousand Oaks: Sage. 